\title{
Air pollution and society
}

\author{
P. Brimblecombe
}

School of Environmental Sciences, University of East Anglia, Norwich NR4 7TJ, UK

\begin{abstract}
Air pollution is as much a product of our society as it is one of chemistry and meteorology. Social variables such as gender, age, health status and poverty are often linked with our exposure to air pollutants. Pollution can also affect our behaviour, while regulations to improve the environment can often challenge of freedom.
\end{abstract}

\section{Introduction}

We are all familiar with the headlines that tell us how bad air pollution is. Inevitably these reminded that it is getting worse. Capital cities almost vie for top position. "The air quality in Hong Kong is worse than it has ever been since records began, according to official figures revealed on Friday." (http://earthfirst.com/hong-kong-air-pollution-worse-than-ever/) or "London air pollution worse than Chernobyl" (http://www.edie.net/news/news_story.asp?id=13173). These cities certainly have air pollution problems although the underlying issues are more complex than this. If we look at the records of most large cities, London for example, shows evidence of much reduced concentrations of primary pollutants such as sulfur dioxide and smoke. The improvements come mostly from reduced coal burning in the $20^{\text {th }}$ century. Hong Kong made a successful and concerted effort in the 1990's to reduce its sulfur dioxide emissions from industrial plant.

Yet improvements rarely seem to be discussed. There is much controversy surrounding the many claims of Bjørn Lomborg in The Skeptical Environmentalist (2001), but it is possible to be sympathetic with the notion that success in environmental issues remains uncelebrated. There are plentiful apocalyptic visions of our future environment and considerable fear about the future. In the case of air pollution there is a need to recognise that air pollution is as much a problem grounded in our social behaviour and perception as it is one of atmospheric chemistry and meteorology. It is this linkage that will be discussed here using some examples of the connection between air pollution and society.

\section{Environmental crime}

The environment has often been associated with crime. Here this should be not be taken to mean that pollution the environment is a crime, but rather there might be links between criminal activity and crime itself. This idea may be strongly embedded in our thinking. Religions, for example, have often placed great importance on cleanliness, such that cleanliness being seen as next to godliness. Thus pollution can take on a spiritual rather than an environmental context. Such ideas are prevalent in early Islamic writers and were characteristic of $19^{\text {th }}$ century Europe from a Christian perspective, when cleaning was thrust onto servants, largely women.

This is an Open Access article distributed under the terms of the Creative Commons Attribution-Noncommercial License 3.0, which permits unrestricted use, distribution, and reproduction in any noncommercial medium, provided the original work is properly cited. 
The links can go further than this. For example, in Victorian London thoughtful commentators saw Jack the Ripper's crimes in the East End in a way that is quite different from our modern perceptions. These seem framed by so many films and novels about the Ripper and other serial killers. A contemporary fragment in the satirical magazine Punch describes a more social origin for the murders:

There floats a phantom on the slum's foul air,...

Red handed, ruthless, furtive, unerect

"Tis murderous crime - the Nemesis of Neglect!"

So there were two crimes, the obvious killing of the women, but the social crime against the poor of London, but also hints that there is something in the air that catalyses this.

At the time London was plagued by thick polluted fogs (catalysed by the formation of droplets around sulphuric acid derived from the oxidation sulfur dioxide in coal smoke). Although Jack the Ripper only prowled the city on fine evenings he has become indelibly associated with the London Fog. This social perception was reinforced by Hitchcock's silent Ripper movie of 1927 The Lodger: A Story of the London Fog. The public vision of the Ripper now presents him as using the fog to conceal his movements. Fog as a popular motif was explored in the Victorian detective story and was able to cloak criminal activities, but to the reader of the story, it was as impenetrable as the mystery being told. In the case of Sherlock Holmes novels, the mystery was even concealed from his fictional biographer Watson, who rarely had the foggiest of what was happening. In Los Angeles of the $20^{\text {th }}$ century things were different. Here stories of hard boiled detectives, such as Raymond Chandler's Philip Marlowe, work within the photochemical smog. However, visibility is not a problem, but the irritant cocktail of chemicals which seems an explanation of criminal activity. Take for example:

"in the hot glow of an August morning. The smog was already coalescing into a solid sheet, burying the Hollywood Hills in a blinding pall that would remain for weeks as the foul summer air compressed itself into a burden on the lungs, the mind and the human heart." M.L. Gregory, Equal to Princes (1986).

Here we see that the air pollution is not simply affecting our health, it affects our entire wellbeing and moral judgement. In this novel about corrupt film moguls it becomes an explanation for their actions. Equally relevant is Joel Schumacher's film Falling Down (1993) where protagonist William Foster (Michael Douglas) is stuck in traffic jam - pollutants spew from cars. He abandons his vehicle and goes on a shooting rampage across the suburbs. Air pollution again is used as a driver for this.

The scientific evidence to relate criminality is more difficult to resolve [1]. Some of the pollutants found in modern photochemical smog, the aldehydes and peroxyacetylnitrates sting our eyes and likely to make us irritable. Lead deposited from past automotive emissions because it was used as an antiknock compound. The presence of high concentrations of lead in the environment have been linked to criminal behaviour. Childhood exposure to lead has been linked with attention deficits, hyperactivity anti-social behaviour and lowered IQ. A long-term study found that higher blood lead levels correlated with more arrests, thus linking the metal to criminal behaviour [1]. It is important not to see our society driven by simple mechanistic processes such as lead poisoning and delinquency is associated with a complex array of factors: weak parent-child attachment, lax supervision and poor performance at school. Nevertheless the social impacts are seen in the relation between a broad range of stress related issues and air pollution discussed over many years by Evans and his co-workers including depression anxiety and hostility [1].

\section{Freedom and choice}

Politicians in the $20^{\text {th }}$ century increasingly had to confront the notion that regulations framed for an improved environment would come at the cost of free choice. In developing the landmark UK Clean Air Act of 1956 it was evident that coal smoke from the domestic chimney was a key source of London's killer smogs. The emerging law would need to regulate domestic fuel and confront the issue of freedom of choice, because people would no longer be free to burn whatever they chose in their own homes. This was a radical change. It may well be that this legislation might be seen as not so important 
because it continued the improvements to air pollution in UK cities, but rather its acceptance of the notion that a better environment was possible and worthwhile despite the fact that at times it would restrict our individual freedom [2].

The issue of personal choice that confronts $21^{\text {st }}$ century air pollution regulation relates to private transport. There are increasing controls and restrictions placed on motorists and London has taken some pioneering approaches to reducing automobile emissions. Mayor Ken Livingstone was willing to confront issues of personal freedom by promoting a system of congestion charges for vehicles accessing the central parts of the city. During its development it was a source of some public protest. Additionally, Westminster City Council challenged the plans on the basis that they would increase pollution and were a breach of human rights to people living on the boundary of the planned congestion charging zone. Despite this the charges went ahead and there were reductions in amount of congestion on central London streets. Air pollution was not a key focus of the regulations, and given the small area of London affected by the charges it was hardly likely that there would be a profound change in air quality. Nevertheless, it has been argued that there are some improvements especially at the roadside. These have been attributed, not only by lowering the number of vehicles, but also through improved traffic flow [3]. Concerns that the concomitant increase in the number of buses would raise the concentrations of fine particulate matter appeared misplaced as newer vehicles have lower emissions. Despite the positive outcomes, congestion charging has not been easy to adopt in other UK cities such as: Edinburgh, Manchester, Coventry, Birmingham and Leeds. Typically referenda of citizens have, perhaps not surprisingly, rejected charging for access to the inner city.

There is a further parallel to be seen between the introduction of the Clean Air Act and congestion charges. When they were to be implemented some argued that they would not work because there were inadequate mechanisms to support the new systems. In the case of smokeless zones under the Clean Air Act alternate smokeless fuels were required and in 1955 smokeless grates were being installed in council houses in Crawley in southern England, but smokeless fuels were not available in large enough quantities. In London 2003 there we fears that public transport would be unable to cope, despite the increases in the number of buses. However, the use of public transport changed only slightly.

A further area of public choice has been the increased tendency for children to be driven to school. The school run not only leads to congestion and higher emissions, but there are also issues regarding reduced social interactions for children who do not have the opportunity to travel with peers. Parents often drive children to school because of fears over the safety of their children and occasionally because they worry about their exposure to air pollutants. This, despite the observation that the air pollution near schools increases at the beginning and end of the school day [4].

\section{Lifestyle, age and gender}

Our lifestyles have changed. We spend so much time indoors now that it may well be unrealistic to expect our exposure to air pollutants to always be just the sum of those that come through the window. There are indoor sources, such as combustion during heating and cooking or outgassing from building materials. Melia and his co-workers have investigated gas cooking and suggest that this has the potential to increase indoor exposure to $\mathrm{NO}_{2}$. In kitchens this can lead to an increased risk of respiratory illnesses, especially among children [5]. Construction materials and furnishings outgas volatile compounds over time as they age or degrade [6], which is an important source as we often chose to cover large areas with fabrics. Additionally energy saving have often meant decreased air change, which allows pollutants to accumulate to higher concentrations.

The issue of freedom of choice is very apparent in the home. We make very personal choices about the way we furnish our interiors. Furthermore we perceive this environment as essentially safe and unpolluted compared with the risks posed by urban world outside. It is often hard for people to accept that there problems of indoor pollutants that can be severe. However, they are being considered more and more by parents whose children have allergies. Here there has been much enthusiasm for natural materials, but it is important to recognise that some such as paints based on plant terpenes can release highly reactive volatiles to the indoor environment. However, natural materials have often been in use for a long time which means that correct approaches to there use and installation are more widely known. 
The emission of formaldehyde from many furnishings was a risk identified in the second half of the $20^{\text {th }}$ century, especially after formaldehyde was suspected to be carcinogenic. Rather than try and regulate its concentration in indoor air many governments instead regulated its presence in materials used in homes. The UK Building Regulations to prohibit the use of urea formaldehyde foam in buildings and to control its installation elsewhere.

Further pressures can arise because our activities in the home have changed. Smoking, drinking, cleaning and cooking all influence indoor air pollution. New relationships with work, and most particularly the gender balance and in future the age of the working population affect our exposure to pollutants, especially those in the home and kitchen. Some indoor air pollution problems, such as sick building syndrome, raise important sociological issues. Sick building syndrome is characterised by combination of ailments experienced in interior spaces most often associated with poor ventilation. It is most apparent among the occupants of new buildings. There is no clear understanding about its origin. Its occurrence is frequently associated with elevated concentrations of a range of organic compounds, but they are usually well below the levels where health affects would be expected. The lack of ready explanations for sick building syndrome have caused some to argue there are wider issues involved. Health effects, are sometimes more widely found among the disenfranchised users of the interior air [7].

Exposure to indoor air pollution can also be the result of poverty or gender [8]. particularly in poorer parts of cities in South America, Africa or Asia. Poor people have less access to the more expensive cleaner fuels for cooking and heating. Additionally in these indoor environments it is often women and children that have the greatest exposures

There can be even more subtle effects of our changing lifestyle. The hot summer of 2003 saw a large number of excess deaths among the elderly people in France. Some blamed this on the heat while others implicated the high concentrations of ozone, but there was also widespread dismay at the social structure within our modern society that exacerbated the effects. There is an increasing tendency for old people to live alone rather than in an extended family, and a desire for lengthy summer holidays both among families and the health professionals. This meant that in the urban centres, where elderly people suffered, there was little support for them when everyone was away on holiday. It is easy to dismiss this simplistic scenario as too journalistic to be credible, but it reminds us of a reality common throughout the world - our social structures are changing. The old and the vulnerable are frequently outside the structures we are left with, which can seriously exacerbate the health effects of air pollution [9].

\section{Climates of fear}

This essay started with the idea that our environmental vision sees things getting worse. Reactions can be especially strong in public vision of air pollutants that are typically seen as not being taken seriously enough by government. Climate change has a public acceptance that various widely between those who believe it is much exaggerated and those who fear a global catastrophe. It is not always clear what drives these differences, but there are worries that responding to environmental issues can have a big impact on our lifestyles. This, as was seen with congestion charges, can create a strong public resistance.

However, societies can sometimes respond to change quite easily. Fashions in clothing change quickly and the media and advertising can promote new garments, although these are typically not designed with our environment in mind. People now wear fewer clothes indoors in winter, yet if the fashion industry persuaded us to wear warmer clothes indoors. There could be great saving as Heating accounts for about a third of the UK carbon emission, but between 1970 and 2000 the average temperature in centrally heated homes increased from $14.5^{\circ} \mathrm{C}$ to $18.1{ }^{\circ} \mathrm{C}$. a $1{ }^{\circ} \mathrm{C}$ decrease in indoor temperatures could give a $2 \%$ reduction in UK carbon emissions. Huge effort is spent creating a desire to buy new cars. Although these can sometimes be less polluting models, there is rarely a parallel enthusiasm for creating a positive image for public transport, in cities where it is poorly used. Hope may lie with the environmental movement which has often been effective in promoting lifestyles that seemed more ecologically sensitive [10]. 
Our modern environmental thinking is increasingly influenced by the media and organisations Greenpeace and Friends of the Earth, although these in their best instances involve lay out the scientific support. In the modern $20^{\text {th }}$ century thinking was much influenced by visions of catastrophe that had its origins in notions of religious apocalypse, perhaps science fiction [11] and ecological models [12]. The potential for nuclear war created doomsday scenarios that haunted many in the 1950s and 1960s. By the late 1960s other issues were interpreted within an apocalyptic framework: droughts, food shortage, pesticides, pollution, and population growth. They were embodied in popular books, such as Ehrlich's The Population Bomb (1968), Alvin Toffler's Future Shock (1970), Gordon Rattray Taylor's The Doomsday Book (1972), and Limits to Growth (1972) that have had added environmental elements to a dystopian vision of the future. At the end of the $20^{\text {th }}$ century AIDS, the millennium bug and greenhouse warming all offered the potential for newer visions of apocalypse. The problem with these representations is that while raising awareness of important issues, they can paralyse us if the suggest failure is inevitable.

\section{Interfacing with politics}

The wide array of environmental threats and the subtle nature of their origin often left the public confused. Politicians found the scientific debate that surrounded these issues equally confusing [9]. The environment is increasingly seen as an important part of the education system, although public concern has not always been matched by public understanding. The sense that the environment is under continued threat to the environment remains and reinforced by an ease of access to graphic information through the media and more recently the internet. Contemporary air pollution management stresses the importance of reporting air pollution concentrations to the public. The data has often been received with little enthusiasm and can even give a sense that it is really bad, simply because it is reported. Others mistrust the data because it looks too good [13]. Some mistrust arises because we don't trust government statistics.

Global environmental problems level can expose further subtlety [9]. Environmental movements have suffered from similar tensions between local and global issues. They have often tried to engage with the public: "think globally act locally" and although this is appealing it does not always alleviate the tensions between local campaigners and those with more strategic interests. Additionally global change can occur over timescales much longer than political careers, issues are expensive to solve and remote to the concerns of an electorate. It has been argued that a politician's vision is only as far as the next election. Thus democratic structures may not be effective at coping with long-term (and perhaps geographically distant) issues such as global warming which take place over many decades. Long term issues such as climate change and sea level rise are all to easy ignore, while immediate issues such as health can feature prominently in political decisions making that neglects global issues, aesthetics or cultural landscapes. These are more difficult to bring to the top of political agendas.

\section{Conclusions}

Examples given here show that air pollution problems are deeply connected with our society. They have a subtlety that goes well beyond the expectations that we might have from considering chemistry or meteorology. An improved environment seems to place some limits on our freedom, but because environments impacts are spread unevenly across society, improved environmental quality has the potential to make more equitable, and hence freer, society.

\section{References}

1. P. Brimblecombe, European Physical Journal Special Topics 1, 47 (2009)

2. P. Brimblecombe, Weather 61, 311 (2006)

3. S. D. Beevers and D. C. Carslaw, Atmospheric Environment 39 (1), 1 (2005) 
4. E. Hopley and P. Brimblecombe, Clean Air and Environmental Protection 32, 75 (2002)

5. R. J. Melia, C. D. Florey, S. Chinn, R. W. Morris, B. D. Goldstein, H. H. John, and D. Clark, The Tokai journal of experimental and clinical medicine 10, 3775 (1985)

6. E. Uhde and T. Salthammer, Atmospheric Environment 41, 3111 (2007); P. Brimblecombe, in Materials for Energy Efficiency and Thermal Comfort in Buildings, edited by R. Matthew and M. Hall (Woodhead Publishing,, Cambridge, 2010), pp. 148

7. L. Pommer, J. Fick, J. Sundell, C. Nilsson, M. Sjostrom, B. Stenberg, and B. Andersson, Indoor Air 14 (1), 16 (2004)

8. M. Adonis and L. Gil, Indoor and Built Environment 10 (3-4), 138 (2001)

9. P. Brimblecombe, Globalizations 2, 429 (2005)

10. J. Porritt and D. Winner, The Coming of the Greens (Fontana, London, 1988)

11. P. Brimblecombe, in Wird Kassandra heiser? Beitraege zu einer Geschichte der "falschen Öko-Alarme," edited by F. Uekoetter and J. Hohensee (Steiner, Stuttgart, 2004), pp. 42

12. J. McCormack, The Global Environmental Movement (Belhaven Press, London, 1989)

13. K. Bickerstaff and G. Walker, Global Environmental Change-Human and Policy Dimensions 11, 133 (2001) 